Egyptian Journal of Aquatic Biology \& Fisheries

Zoology Department, Faculty of Science,

Ain Shams University, Cairo, Egypt.

ISSN $1110-6131$

Vol. 24(5): 393 - 402 (2020)

www.ejabf.journals.ekb.eg

\title{
Genetic Relationship Between Two Species of Genus Dicentrarchus Based on SCoT Markers and SDS-PAGE
}

\author{
Ali H. Abu Almaaty*, Hala E. Abd-Alaty, Osama A. Abbas and \\ Mohamed K. Hassan \\ Zoology Department, Faculty of Science, Port Said University, Port Said, Egypt. \\ "Corresponding Author: ali_zoology_2010@yahoo.com
}

ARTICLE INFO

Article History:

Received: July 24, 2020

Accepted: Aug. 9, 2020

Online: Aug. 14, 2020

Keywords:

Genetics,

SCoT,

Bands,

SDS-PAGE,

Moronidae,

Fish.

\section{ABSTRACT}

In the present study, start codon targeted (SCoT) technique was used for measuring the genetic variability between two fish species of family Moronidae (Dicentrarchus punctus and Dicentrarchus labrax), these species were collected from the Mediterranean Sea, Port Said, Egypt. Eleven SCoT primers were used in the study of generating different lengths of amplicons that ranged from 150bp to 1800bp (SCoT-2, SCoT-3, SCoT-4, SCoT-6, SCoT-7, SCoT-8, SCoT-9, SCoT-10, SCoT-28, SCoT-35 and SCoT-46). The polymorphism percent ranged from $18 \%$ with SCOT-28 primer to $75 \%$ with SCOT- 6 . The genetic similarity between the two species was $75.5 \%$. Protein analysis using Sodium dodecyl sulfate polyacrylamide gel electrophoresis (SDS-PAGE) was also performed in this study producing a total of 22 bands that ranged in size from $19 \mathrm{KD}$ to $200 \mathrm{KD}$. Each of the two species produced 22 bands.

\section{INTRODUCTION}

The importance of genetic data increases, it can help in conserving and managing of endangered and threatened species (Allendorf and Luikart, 2007). These data also can be used for identification of species and population which have a reduced genetic diversity (Saccheri, et al., 1998). Recently, more complex conservation issues have been addressed by genetic data including effective population size estimation (Peterson and Ardren, 2009; Small et al., 2009).

Morphological characters are not a robust method in identification. In fish especially, morphological plasticity among individuals of the same species is connate. For example, individuals of the same species may differ in the body color depending on habitat, diet regime and season (Price, et al., 2008).

Studying of population structure is done using molecular techniques by analyzing colonization patterns, dispersal and gene flow among populations over a different of geographical scales. Deductions made from datasets can be impacted by the use of variable molecular techniques that based on nuclear DNA such as SCoT markers and 
microsatellites or protein analysis such as Sodium Dodecyl Sulfate Polyacrylamide (SDSPAGE) gel electrophoresis (Duran, et al., 2004).

Molecular analysis has considered as a viable alternative in species identification and taxonomy. Species fitness for surviving in a niche environment is controlled by a group of biological attributes and any changes in the niche environment may lead to genetic drift, polymorphism and mutation as fish adaptation; at molecular level, molecular markers such as DNA marker can be used to detect species or individual uniqueness where individuals of the same species have their own DNA sequence that vary, to some extent, from individuals that belong to other species (Sbordoni, 2010).

In fish identification, the common applied DNA analyses are simple sequence repeat (SSR), random amplified polymorphic DNA (RAPD), amplified fragment length polymorphism (AFLP), expressed sequence tag (EST), length polymorphism (RFLP) and single nucleotide polymorphism (SNP) markers (Sampaio, et al., 2003; Teletchea, 2009; Chauhan and Rajiv, 2010; Khoo, et al., 2011; Kress, et al., 2015).

SCoT is a benefit method for assessment of structure, DNA fingerprinting and genetic diversity of different species; this is because this technique was used successfully in a wide range of plant species studies such as grape, potato, rice and mango (Luo, et al., 2010; Gorji, et al., 2011; Xiong, et al., 2011; Amirmoradi, et al., 2012; Gorji, et al., 2012; Guo, et al., 2012; Que, et al., 2014; Vivodík, et al., 2016). SCoT technique uses a single reverse and forward primer (Bhattacharyya, et al., 2013). Advantages of SCoT technique are simple primer design, simple operation, highly effective polymorphism, low cost and good reproducibility (Chen, et al., 2009).

Proteins of the animal cells are species-specific macromolecules; sodium dodecyl sulfate polyacrylamide gel electrophoresis (SDS-PAGE) is a molecular biomarker in which proteins are separated according to their molecular weight; it is an effective technique used for studding variation between species and illustrate the metabolic level of species under the study (Muhammad, et al., 2018)

Studying of the genetic variability of fish species using SCoT technique is limited; so, the present study was aimed to using SCoT for measuring the genetic relationship between a very closely related species of family Moronidae (Dicentrarchus punctus and Dicentrarchus labrax) and analysis the tissue proteins of the two fish species using SDS-PAGE.

\section{MATERIALS AND METHODS}

\section{Samples collection}

Two fish species of family Moronidae (Dicentrarchus labrax and Dicentrarchus punctus) (Fig.1) were obtained from the Mediterranean Sea. Appropriate size of muscle tissues were obtained from the four fish species and were frozen at $-20^{\circ} \mathrm{C}$.

\section{DNA Extraction and SCoT-Technique}

DNeasy Mini Kit (Qiagen) was used in DNA extraction from muscles of the two fish species. NanoDrop was used for measuring the genomic DNA concentration. Eleven SCoT primers (SCoT-2, SCoT-3, SCoT-4, SCoT-6, SCoT-7, SCoT-8, SCoT-9, SCoT-10, SCoT-28, SCoT-35 and SCoT-46) as shown in Table (1) were used in PCR reaction. Perkin-Elmer/GeneAmp® PCR System 9700 (PE Applied Biosystems) was used for performing PCR amplification. It was programmed to fulfill 40 cycles after an initial 
denaturation cycle for $5 \mathrm{~min}$ at $94^{\circ} \mathrm{C}$. Each cycle programed to three steps; a denaturation step for $1 \mathrm{~min}$ at $94^{\circ} \mathrm{C}$, an annealing step for $1 \mathrm{~min}$ at $50^{\circ} \mathrm{C}$, and an elongation step for 1.5 $\min$ at $72^{\circ} \mathrm{C}$.

\section{Detection of the PCR Products}

$1.5 \%$ agarose gel with ethidium bromide was used for running the amplified products and the buffer used was $1 \mathrm{X}$ TBE buffer; the run was at $95 \%$ volts. UV light was used for visualizing PCR products and a Gel Documentation System (BIO-RAD 2000) was used for photographing.

\section{Data Analysis}

The banding patterns resulted from SCoT primers were compared to evaluate the genetic relatedness of fish samples under the study. Products of the amplification were scored as ' 1 ' for presence and ' 0 ' for absence of bands. The cluster analysis was made through the similarity matrix. The cluster analysis was used for organizing the resulted data into meaningful structures developing the taxonomies (Sneath and Sokal, 1973). The distances between accessions are showed by Dice coefficient through PAST program after each accession represented its own cluster.

\section{SDS-PAGE analysis}

Muscular proteins were separated based on their molecular weight by Sodium dodecyl sulfate polyacrylamide gel electrophoresis (SDS-PAGE). Proteins of muscle tissue were extracted according to Fadda et al., (1999). one gram of muscular tissue was homogenized with $9 \mathrm{ml}$ PBS (phosphate buffer solution), and then the sample was centrifuged for $15 \mathrm{~min}$ at $10000 \mathrm{rpm} ; 4^{\circ} \mathrm{C}$. The supernatant contained proteins and was transferred to a clean eppendorf. Treatment buffer (1\% SDS, 10\% glycerol, 10 mMTrisHCL PH 6.8, 1mMEDTA, DTT (dithiolthreitor) and pinch of bromophenole blue) was added to the protein sample and boiled for $5 \mathrm{~min}$ at $90^{\circ} \mathrm{c}$. Protein solution and protein marker were loaded into polyacrylamide gel; the run was carried out at 100 volt in $1 \mathrm{x}$ Tris/glycine- SDS-running buffer. After electrophoresis, staining of the gel was occurred using $50 \mathrm{ml}$ of staining solution (10\% acetic acid, $0.125 \%$ coomassie blue R-250 and $50 \%$ methanol), and then gel was dried and photographed. SDS-PAGE was performed according to (Laemmli, 1970). Molecular weight of protein patterns were stated according to Weber et al., (1972).

Table 1. The sequence of SCoT primers, A: Adenine, T: Thymine, G: Guanine, C: Cytosine

\begin{tabular}{|c|c|}
\hline Primer Name & Sequence \\
\hline SCoT-02 & 5'-ACCATGGCTACCACCGGC-3' \\
\hline SCoT-03 & 5'-ACGACATGGCGACCCACA-3' \\
\hline SCoT-04 & 5'-ACCATGGCTACCACCGCA-3' \\
\hline SCoT-06 & 5'-CAATGGCTACCACTACAG -3' \\
\hline SCoT-07 & 5'-ACAATGGCTACCACTGAC -3' \\
\hline SCoT-08 & 5'-ACCATGGCTACCACGGCA-3' \\
\hline SCoT-09 & 5'-ACAATGGCTACCACTGCC -3' \\
\hline SCoT-10 & 5'-ACAATGGCTACCACCAGC-3' \\
\hline SCoT-28 & 5'-CAACAATGGCTACCACCA-3' \\
\hline SCoT-35 & 5'-AACC $\underline{\text { ATGGCTACCACCAC-3' }}$ \\
\hline SCoT-46 & 5'-ACCATGGCTACCACCGCC-3' \\
\hline
\end{tabular}




\section{RESULTS}

\section{Start codon targeted analysis}

In this study, Dicentrarchus punctus and Dicentrarchus labrax (Fig.1) of family Moronidae were collected from Mediterranean Sea for Studying the genetic variability between them by using eleven SCoT primers. All eleven primers generated strong amplification profiles with distinct bands that revealed DNA polymorphism between the two species under study as shown in (Figures 2, 3 and 4). Gene profiler computer software program was used for analyzing the banding patterns of the DNA fragments. The eleven SCoT primers detected a total of 122 DNA fragments (Table 3), with an average of 11 fragments per primer. The total number of amplified fragments varied from 7 (SCoT-9) to 16 (SCoT-3) primers. Of the 122 amplified bands, 74 were monomorphic bands and 48 unique bands with polymorphism ranged from $18 \%$ to $75 \%$ as shown in Table (2).

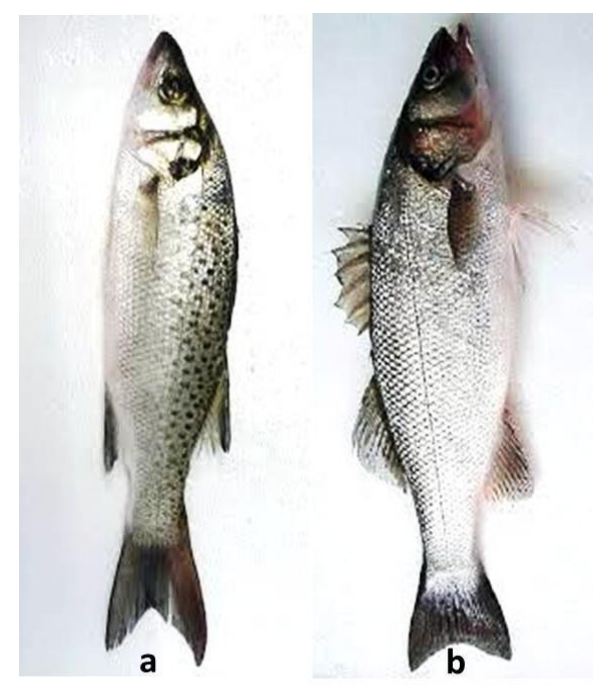

Fig. 1. Photographs of Dicentrarchus punctus (a) and Dicentrarchus labrax (b)

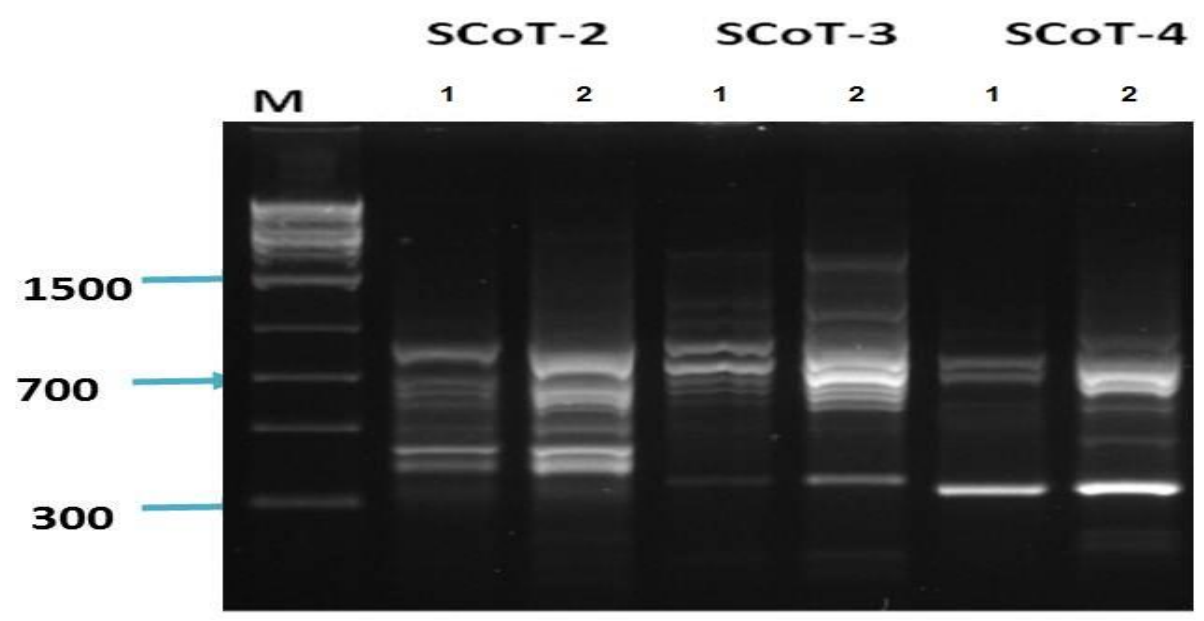

Fig. 2. SCoT profile of two fish species using SCoT primers (SCoT-2, SCoT-3 and SCoT-4). M refers to DNA ladder marker (1- Dicentrarchus punctus and 2-Dicentrarchus labrax). 
Table 2. Percentage of polymorphism, molecular weight and number of total bands, monomorphic bands, polymorphic and unique bands generated by eleven SCoT primers with two fish species (1- Dicentrarchus punctus and 2- Dicentrarchus labrax).

\begin{tabular}{|c|c|c|c|c|c|c|c|}
\hline \multirow[t]{2}{*}{$\begin{array}{l}\text { Primer } \\
\text { code }\end{array}$} & \multicolumn{2}{|c|}{$\begin{array}{c}\text { No. of } \\
\text { amplified } \\
\text { bands }\end{array}$} & \multirow[t]{2}{*}{$\begin{array}{c}\text { Total } \\
\text { amplified } \\
\text { bands }\end{array}$} & \multirow[t]{2}{*}{$\begin{array}{c}\text { Size of } \\
\text { amplified } \\
\text { bands }\end{array}$} & \multirow[t]{2}{*}{$\begin{array}{c}\text { NO. of } \\
\text { monomorphic } \\
\text { bands }\end{array}$} & \multirow[t]{2}{*}{$\begin{array}{l}\text { No. of } \\
\text { unique } \\
\text { bands }\end{array}$} & \multirow[t]{2}{*}{ Polymorphism\% } \\
\hline & 1 & 2 & & & & & \\
\hline SCOT-2 & 10 & 12 & 13 & 250-850bp & 9 & 4 & $31 \%$ \\
\hline SCOT-3 & 12 & 13 & 16 & 150-1800bp & 9 & 7 & $44 \%$ \\
\hline SCOT-4 & 6 & 9 & 10 & 200-1000bp & 5 & 5 & $50 \%$ \\
\hline SCOT-6 & 4 & 6 & 8 & 250-750bp & 2 & 6 & $75 \%$ \\
\hline SCOT-7 & 10 & 9 & 12 & 200-1400bp & 7 & 5 & $42 \%$ \\
\hline SCOT-8 & 8 & 7 & 10 & 230-800bp & 5 & 5 & $50 \%$ \\
\hline SCOT-9 & 6 & 6 & 7 & 250-850bp & 5 & 2 & $28 \%$ \\
\hline SCOT-10 & 9 & 8 & 11 & 300-900bp & 6 & 5 & $45 \%$ \\
\hline SCOT-28 & 10 & 10 & 11 & 180-500bp & 9 & 2 & $18 \%$ \\
\hline SCOT-35 & 9 & 12 & 12 & 170-700bp & 9 & $\overline{3}$ & $25 \%$ \\
\hline SCOT-46 & 9 & 11 & 12 & 190-550bp & 8 & 4 & $33 \%$ \\
\hline Total & 93 & 103 & 122 & 150-1800bp & $\overline{74}$ & $\overline{48}$ & $39 \%$ \\
\hline
\end{tabular}

Following are the amplification results of the two fish species obtained by the examined primers:

\section{Dicentrarchus punctus}

SCoT primers with this species produced different band patterns of 93 bands ranged in size from $170 \mathrm{bp}$ in the primer (SCoT-35) to $1800 \mathrm{bp}$ in (SCoT-3). The generated bands ranged in number from 4 in (SCoT-6) to 12 in (SCoT-3).

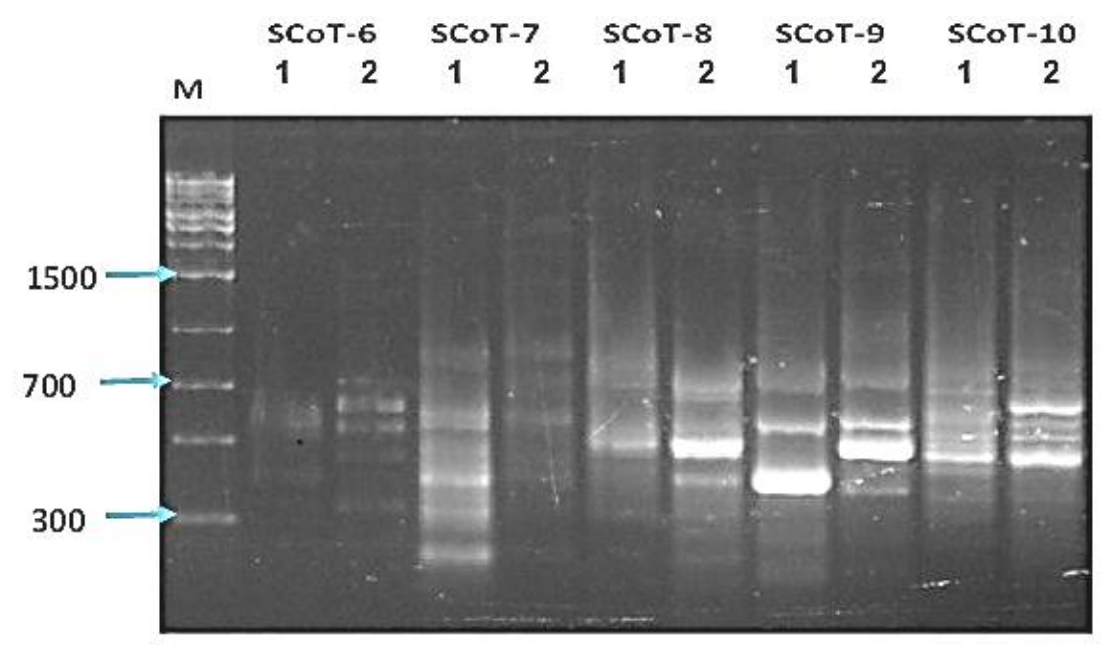

Fig. 3. SCoT profile of two fish species using SCoT primers (SCoT-6, SCoT-7, SCoT-8, SCoT-9 and SCoT-10). M refers to DNA ladder marker (1-Dicentrarchus punctus and 2-Dicentrarchus labrax).

\section{Dicentrarchus labrax}

In this species, SCoT primers produced band patterns of 103 bands ranged in size from $150 \mathrm{bp}$ to $1800 \mathrm{bp}$ in primer (SCoT-3). The generated bands ranged in number from 6 in (SCoT-6 and SCoT-9) to 13 in (SCoT-3). Genetic similarity between the two species was $75.5 \%$ as shown in Table (3). 


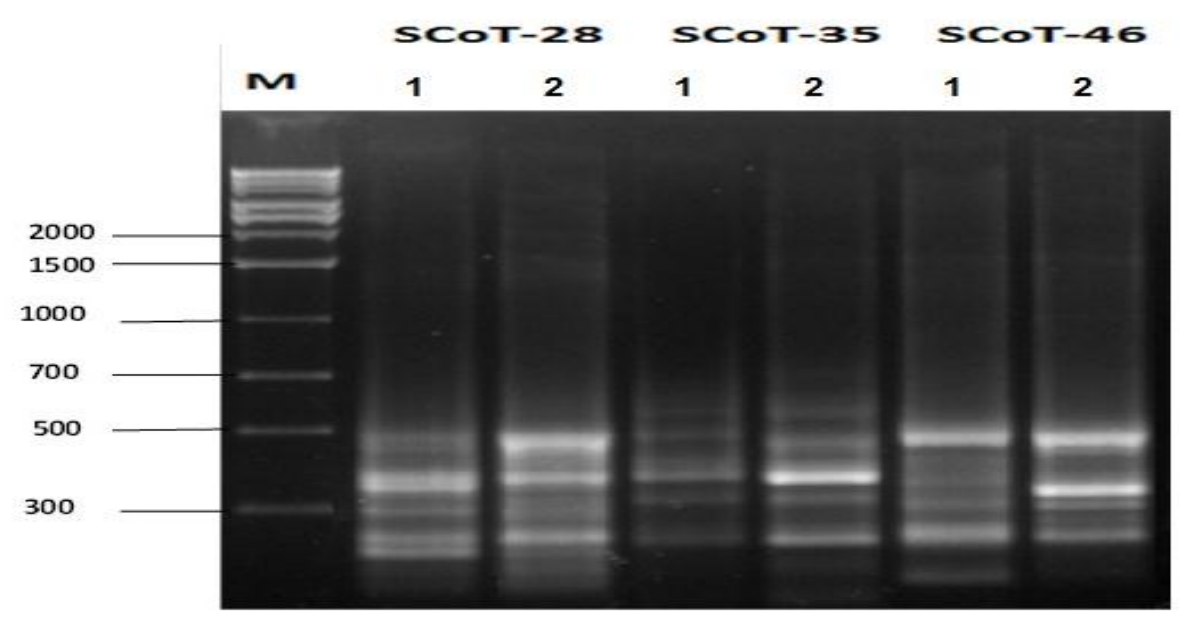

Fig. 4. SCoT profile of two fish species using SCOT primers (SCoT-28, SCoT-35 and SCoT-46). M refers to DNA ladder marker (1-Dicentrarchus punctus and 2-Dicentrarchus labrax).

Table 3. Averages of genetic similarities (\%) estimated by molecular SCoT primers, adopting the arithmetic complement of Jaccard coefficient for two fish species of family moronidae. (1- Dicentrarchus punctus and 2-Dicentrarchus labrax).

\begin{tabular}{|c|c|c|}
\hline & 1 & 2 \\
\hline 1 & 100 & \\
\hline 2 & 75.5 & 100 \\
\hline
\end{tabular}

\section{SDS-PAGE analysis}

Protein analysis using Sodium dodecyl sulfate polyacrylamide gel electrophoresis (SDS-PAGE) generated a total of 22 bands that ranged in size from 19KD to 200KD. Each of the two species produced 22 bands as shown in Table (4) and (Fig.5).

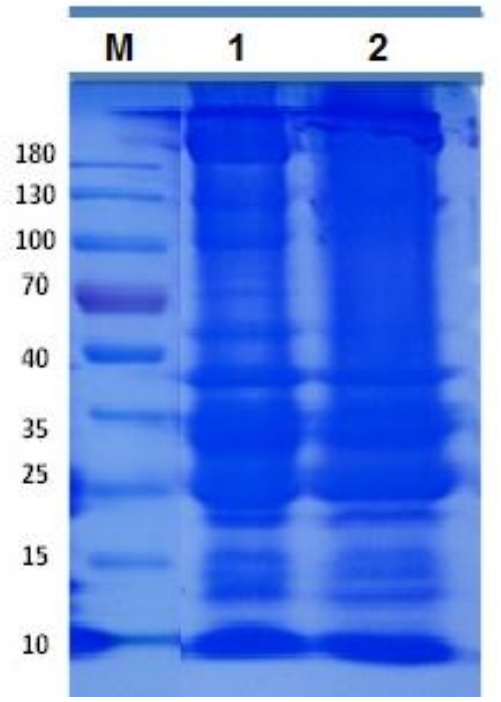

Fig. 5. Protein banding patterns of SDS-PAGE (1- Dicentrarchus punctus and 2- Dicentrarchus labrax). 
Table 4. Bands of SDS-PAGE protein for two fish species of Moronidae (1- Dicentrarchus punctus and 2Dicentrarchus labrax).

\begin{tabular}{|c|c|c|}
\hline MW & $\mathbf{1}$ & $\mathbf{2}$ \\
\hline $\mathbf{2 0 0}$ & 1 & 1 \\
\hline $\mathbf{1 7 8}$ & 1 & 1 \\
\hline $\mathbf{1 6 9}$ & 1 & 1 \\
\hline $\mathbf{1 3 7}$ & 1 & 1 \\
\hline $\mathbf{1 2 7}$ & 1 & 1 \\
\hline $\mathbf{1 2 4}$ & 1 & 1 \\
\hline $\mathbf{1 0 9}$ & 1 & 1 \\
\hline $\mathbf{9 2}$ & 1 & 1 \\
\hline $\mathbf{8 5}$ & 1 & 1 \\
\hline $\mathbf{7 1}$ & 1 & 1 \\
\hline $\mathbf{5 9}$ & 1 & 1 \\
\hline $\mathbf{4 6}$ & 1 & 1 \\
\hline $\mathbf{4 2}$ & 1 & 1 \\
\hline $\mathbf{3 6}$ & 1 & 1 \\
\hline $\mathbf{3 3}$ & 1 & 1 \\
\hline $\mathbf{3 2}$ & 1 & 1 \\
\hline $\mathbf{3 0}$ & 1 & 1 \\
\hline $\mathbf{2 6}$ & 1 & 1 \\
\hline $\mathbf{2 4}$ & 1 & 1 \\
\hline $\mathbf{2 2}$ & 1 & 1 \\
\hline $\mathbf{1 9}$ & 1 & 1 \\
\hline & 1 & 1 \\
\hline
\end{tabular}

\section{DISCUSSION}

DNA bands and Muscles protein profile of two species of geneus Dicentrarchus (Dicentrarchus punctus and Dicentrarchus labrax) were investigated in this study using SCoT markers and SDS-PAGE. The genetic relationship between two species was indicated.

With the development of DNA-based molecular markers; Start codon target (SCoT) technique was developed based on the conserved sequences that flank ATG start codon of genes. SCoT is a reproducible marker and it can be used for bulk segregation analysis, genetic analysis and quantitative trait loci mapping SCoT is similar to ISSR in using a single primer that acts as the reverse and the forward primer (Collard and Mackill, 2009). Using start codon targeted technique was applied to determine genetic diversity and for quantitative trait loci mapping and DNA fingerprinting in different species (Cabo et al., 2014).

According to Mar'ie and Allam, (2017) there were not studies in polymorphism in fishes based on Start Codon Targeted; at least in Egypt. They began the investigation of the efficiency of this technique on tissues of fishes through estimation of relationships and genetic diversity between three of closely related species in family Carangidae (Caranx melampygus, Carangoides bajad and Caranx sexfasciatus collected from Red Sea of Hurghada, Egypt.

Assessment of polymorphism between fish species is commonly studied through electrophoresis of muscle protein (Haniffa et al., 2017). Proteins in complex extracts are widely analyzed by SDS-PAGE (Sodium dodecyl sulfate- polyacrylamide gel electrophoresis) which is first described by Laemmli, (1970). 
The genetic similarity and muscles protein bands among four species of fishes (Puntius tetrazone, Pethia nigrofasciatus, Brachydanio rerio and Barbonymus schwanenfeldii) were concluded using molecular marker and SDS-PAGE (Abu Almaaty et al., 2020)

This study indicates the possibility of usage of SCoT technique as a tool for differentiating between the closely related species. The genetic similarity between the two species was $75.5 \%$ by using eleven SCoT primers. SDS-PAGE analysis produced 22 bands with molecular weight ranging from 19 to $200 \mathrm{KD}$.

\section{CONCLUSION}

SCoT technique is a famous tool for differentiating between plant species, but it is rarely used in fish species differentiation. This study proved that this technique is a successful tool for measuring the genetic relationship between the closely related species and the author recommends studying the genetic relationship among Moronidae species using more SCoT primers and SDS-PAGE technique.

\section{REFERENCES}

Abu-Almaaty A. H.; Bahgat, I. M. and Al-Tahr, Z. M. (2020). Using SDS-PAGE and ISSR as biochemical markers for assessment the genetic similarity and protein analysis of some Cyprinid fish species.- Genetika, 52(1), 161-175.

Allendorf, F. W. and Luikart, G. (2007). Conservation and the genetics of populations 2nd ed. Blackwell publishing. Oxford U. K. 642pp.

Amirmoradi, B.; Talebi, R. and Karami, E. (2012). Comparison of genetic variation and differentiation among annual Cicer species using start codon targeted (SCoT) polymorphism, DAMD-PCR, and ISSR markers. Plant Syst. Evol. 298(9): 1679-1688.

Bhattacharyya, P.; Kumaria, S.; Kumar, S. and Tardon, P. (2013). Start Codon Targeted (SCoT) marker reveals genetic diversity of Dendrobium nobil Lindl., an endangered medicinal orchid species. Gene. 529(1): 21-26.

Cabo, S.; Ferreira, L.; Carvalho, A.; Martins-Lopes, P.; Martín, A. and Lima-Brito, J. E. (2014). Potential of Start Codon Targeted (SCoT) markers for DNA fingerprinting of newly synthesized tritordeums and their respective parents. Journal of applied genetics, 55(3), 307-312

Chauhan, T. and Rajiv, K. (2010). Molecular markers and their applications in fisheries and aquaculture. Advances in Bioscience and Biotechnology. 1: 281-291.

Chen, H.; He, X.; Luo, C.; Gao, M. and Zhu, J. (2009). The optimization of SCoT-PCR system of Longan (Dimocarpus longan). Genomics and Applied Biology, 28(5), 970-974.

Collard, B. C. Y. and Mackill, D. J. (2009). Start Codon Targeted (SCoT) Polymorphism: a simple novel DNA marker technique for generating gene-targeted markers in plants. Plant Mol. Biol. Rep. 27: 86-93.

Duran, S.; Pascual, M. and Turon, X. (2004). Low levels of genetic variation in mtDNA sequences over the western Mediterranean and Atlantic range of the sponge Crambe crambe (Poecilosclerida). Marine Biology. 144(1): 31-35.

Fadda, S.; Sanz, Y.; Vignolo, G.; Aristoy, M. C.; Oliver, G. and Toldra, F. (1999). Characterization of muscle sarcoplasmic and myofibrillar protein hydrolysis caused by Lactobacillus plantarum. Appl. Environ. Microbiol. 65: 3540-3546. 
Gorji, A. M.; Matyas, K. K.; Dublecz, Z.; Decsi, K.; Cernak, I.; Hoffmann, B.; Taller, J. and Polgar, Z. (2012). In vitro osmotic stress tolerance in potato and identification of major QTLs. Am. J. Pot. Res. 89: 453-464.

Gorji, A. M.; Poczai, P.; Polgar, Z.; Taller, J. (2011). Efficiency of arbitrarily amplified dominant markers (SCoT, ISSR and RAPD) for diagnostic fingerprinting in tetraploid potato. Am. J. Pot. Res. 88(3): 226-237.

Guo, D. L.; Zhang, J. Y. and Liu, C. H. (2012). Genetic diversity in some grape varieties revealed by SCoT analysis. Mol. Biol.Rep. 39(5): 5307-5313.

Haniffa M. A.; Sheela P. J.; Milton M. J. and Kavitha K. (2017). Protein profiling for phylogenetic relationship in snakehead species', Iranian Journal of Fisheries Sciences, 16(4), 1178-1186.

Khoo, G.; Lim, T. M. and Phang, V. P. E. (2011). A Review of PCR-Based DNA Fingerprinting Using Arbitrary Primers in Tropical Ornamental Fishes of South East Asia. Journal of Advanced Medical Research. 1: 71-93.

Kress, J. W.; Garcia-Robledo, C.; Uriarte M. and Erickson, D. L. (2015). DNA barcodes for ecology, evolution, and conservation. Trends in Ecology and Evolution. 30: 25-35.

Laemmli, U. K. (1970). Cleavage of structural proteins during the assembly of the head of bacteriophage T4', Nature, 227, pp. 680-685.

Luo, C.; He, X. H.; Chen, H.; Ou, S. J.; Gao, M. P. (2010). Analysis of diversity and relationships among mango cultivars using Start Codon Targeted (SCoT) markers. Biochem. Syst. Ecol. 38(6): 1176-1184.

Mar'ie, Z. A. and Allam, M. (2017). Using start codon targeted (SCoT) polymorphism for genetic diversity analysis of three Red Sea fishes (Family: Carangidae). IOSR Journal of Pharmacy and Biological Sciences, 12, 50-56.

Muhammad, O. I.; Mahmoud, U. M.; Fazio, F., Sayed, A. H. (2018). SDS-PAGE technique as biomarker for fish toxicological studies. Toxicology Reports, 5: 905-909.

Peterson, D. P. and Ardren, W. R. (2009). Ancestry, population structure, and conservation genetics of Arctic grayling (Thymallus arcticus) in the upper Missouri River, USA. Canadian Journal of Fisheries and Aquatic Sciences. 66(10): 1758-1774.

Price, A. C.; Cameron, J.; Weadick-Shim, J. and Rodd, F.H. (2008). Pigments, Patterns, and Fish Behavior. Zebrafish. 5(4): 297-307.

Que, Y. X.; Pan, Y. B.; Lu, Y. H.; Yang, C.; Yang, Y. T.; Huang, N. and Xu, L.P. (2014). Genetic analysis of diversity within a Chinese local sugarcane germplasm based on start codon targeted polymorphism. Bio. Med. Res., Int., 468375.

Saccheri, I.; Kuussaari, M.; Kankare, M.; Vikman, P.; Fortelius, W. and Hanski, I. (1998). Inbreeding and extinction in a butterfly metapopulation. Nature. 392(6675): 491-494.

Sampaio, P.; Gusmao, L.; Alves, C.; Pina-Vaz, C.; Amorim, A. and Pais, C. (2003). Highly polymorphic microsatellite for identification of Candida albicans strains. Journal of Clinical Microbiology. 41: 552-557.

Sbordoni, V. (2010). Strength and Limitations of DNA Barcode under the Multidimensional Species Perspective. Tools for Identifying Biodiversity: Progress and Problems, 275-280.

Small, M. P.; Currens, K.; Johnson, T. H.; Frye, A. E. and Von Bargen, J. F. (2009). Impacts of supplementation: genetic diversity in supplemented and unsupplemented populations of summer chum salmon (Oncorhynchus keta) in Puget Sound (Washington, USA). Can. J. Fish. Aquat. Sci. 66(8).

Sneath, P. H. A. and Sokal, R. R. (1973). Numerical taxonomy; the principles and practice of numerical classification. San Francisco: Freeman Medical Reseach Council Microbial systematic Unit. Leicester, England and Dept. Ecology and Evolution State Univ. New York, Stony Brook, NY.

Teletchea, F. (2009). Molecular identification methods of fish species: Reassessment and possible applications. Reviews in Fish Biology and Fisheries. 19: 265-293. 
Vivodík, M.; Gálová, Z.; Balážová, Ž. and Petrovičová, L. (2016). Start codon targeted (scot) polymorphism reveals genetic diversity in european old maize (zea mays 1.) Genotypes', Potravinarstvo. 10(1): 563-569.

Weber, K.; Pringle, J. R. and Osborn, M. (1972). Measurement of molecular weights by electrophoresis on SDS-acrylamide gel. Methods in enzymology, 26, 3-27.

Xiong, F.; Zhong, R.; Han, Z.; Jiang, J.; He, L.; Zhuang, W. and Tang R. (2011). Start Codon Targeted polymorphism for evaluton of functional genetic variation and relationships in cultivated peanut (Arachs hypogaeal L.). Genotypes. Mol. Biol. Rep. 38(5): 3487-3494. 